\title{
Nueva Francia y Nueva Inglaterra en el contexto de los Tratados de Utrecht (1713). Lucha por el Imperio e Historia Transatlántica/
}

New France and New England in the context of the Treaties of Utrecht (1713). Struggle for the Empire and Transatlantic History

José Manuel de Bernardo Ares

Universidad de Córdoba

Después de fijar las coordenadas espacio temporales del trabajo, así como la óptica interpretativa de la historia política, se analizan los poderes metropolitanos de Francia e Inglaterra en su expansión americana, los poderes autóctonos-amerindios y los poderes coloniales de Nueva Francia y Nueva Inglaterra entre 1661 y 1713.

Palabras Clave: Nueva Francia; Nueva Inglaterra; Tratados de Ryswick y Utrecht; Historia Transatlántica; Guerras de Sucesión; Comercio Transoceánico.

After establishing the spatiotemporal coordinates of the work, along with an interpretive perspective of political history, the metropolitan powers of France and England in their American expansion, autochthonous-Amerindian powers and colonial powers of New France and New England between 1661 and 1713 have been analysed.

KeYwords: New France; New England: Treaties of Ryswick and Utrecht; Transatlantic History; Wars of Succession; Transoceanic Commerce. 


\section{Introducción}

Las causas y consecuencias de los importantes tratados de Utrecht del 11 de abril de 1713 han sido bien estudiadas para Europa, pero no tanto en su estrechísima relación con América. En este trabajo se tendrán en cuenta unas y otras en el contexto interdependiente euro-americano. Pero esta inexcusable «Historia atlántica» hay que abordarla, como mínimo, en un «tiempo coyuntural» (unos cincuenta años), que nos permita entender cabalmente la gran significación internacional de aquellos tratados de Utrecht. De ahí que, si el período de la guerra de Sucesión a la Corona española fue decisivo (1702-1713), no tuvo menos importancia el precedente período de la guerra de sucesión a la Corona inglesa (1689-1697).

Además de precisar estas coordenadas espacio-temporales, se especifica a continuación la óptica o paradigma interpretativo desde el que se analiza el tema básico del trabajo, cual es la estructura y dinámica del poder político de las metrópolis europeas y de las colonias americanas. Se trata, en efecto, de una «Historia política», pero totalmente entroncada con los hechos sociales, económicos y culturales. ${ }^{1}$

Con estas delimitaciones espacio-temporales y teniendo como hilo conductor aquella concepción de la organización política de la sociedad, el tema central de esta colaboración consiste en perfilar la naturaleza de las tres dimensiones interrelacionadas del poder metropolitano de Francia e Inglaterra, del poder autóctono de los aborígenes y del poder colonial de Nuevas Francia y de Nueva Inglaterra con el fin de explicar la caída del imperio colonial francés y el auge del imperio colonial inglés, cuyo proceso se inicia en Ryswick y se consolida en Utrecht.

\section{Coordenadas espacio-temporales: La historia atlántica}

Para John Elliott, al menos en la época colonial, el «Atlántico» es un espacio común de relaciones recíprocas.

That common history, however, at least as far as the colonial period is concerned, cannot and should not be divorced from its wider, Atlantic, context. The interrelation

1 Este trabajo ha sido realizado en el contexto del Proyecto de Investigación HAR2011-24529 (PLUTARCO XXI: Biografías y Procesos desde las perspectivas interdisciplinares de la Historia, la Traductología y la Literatura, 1600-1800), financiado por el Ministerio de Ciencia e Innovación (MICINN) con fondos PGE (Presupuesto General del Estado). 
between Europe and America was constant, and throughout the colonial period Europe remained the standard point of reference for these new American societies. The common history of the Americas was, for three centuries at least, the common history also of the whole Atlantic world. ${ }^{2}$

Elliott recogió esta misma idea de Daniel W. Howe, que se manifestó en este sentido en su discurso inaugural de Oxford en 1993. ${ }^{3}$

Para la fijación conceptual y metodológica de este «mundo atlántico» son imprescindibles los trabajos de Baily, Armitage y Canny. ${ }^{4}$ P. Coclanis, en un artículo sobre la «idea de la historia atlántica» y el «mundo como una isla» de Bailyn, amén de insistir en las extraordinarias consecuencias académico-científicas de la Bailynesque — «can be defined as a complex and elaborate historical design of intersecting and in same cases intertwined parts»-, aboga decididamente por la necesidad historiográfica de elaborar una Historia atlántica, según la que ambas riberas de este mar no se podrían comprender. ${ }^{5}$ Hay que reparar en que Bailyn abordó todos los aspectos de la colonización americana: los políticos, económicos, sociales y culturales.

Para James Muldoon - especialista en historia legal en general y en derecho romano-canónico en particular- el «Atlántico» es el mare nostrum de la modernidad (imperios español, portugués, francés y británico) al igual que el «Mediterráneo» lo fuera de la antigüedad, del Imperio Romano. Aborda esta temática «universal», común, desde la perspectiva de la jurisdicción sobre el mar, comentando las razones de Grotius (mare liberum) y Selden (mare clausum); y desde la perspectiva del derecho romanocanónico - ius commune-, que influyó decisivamente en la articulación de un nuevo orden y, por lo tanto, de una nueva legalidad en el Atlántico después de Westfalia, cuando la diagonal de la contrarreforma bajo la égida del papado, deja paso a la construcción de la Europa horizontal de Estados autónomos. El derecho romano-canónico se convierte en derecho «nacional». Se diluye la universalidad cristiana para dar lugar a la universalidad de la fuerza estatal (estados militares). ${ }^{6}$

2 Elliott, 1998, 40-41; este trabajo está basado en otro suyo publicado en 1996. Ver también Elliott, 1994.

3 Howe, 1993.

4 Bailyn, 1996; Armitage, 1997 y 1999; Canny, 1999.

5 Coclanis, 2002, 169.

6 Muldoon, 1999, 2002 y en prensa a y b; Morton, 1992, 1-40. 


\section{La coyuntura temporal de las dos guerras de Sucesión a las Coronas inglesa y española}

Para comprender el tiempo corto de los tratados de Utrecht de 1713 es imprescindible tener muy en cuenta sus causas, que nos obligan a retrotraernos a un período anterior, que se debe remontar hasta $1661 .{ }^{7}$ Desde esta fecha hasta 1713 se pasó de una alianza entre Francia e Inglaterra contra España y Holanda (1661-1688), a una lucha entre ellas por la hegemonía política en Europa y por la expansión colonial en América durante las guerras de Sucesión a la Corona inglesa (1689-1697) y a la Corona española (1702-1714). Desde una perspectiva atlántica Pierre François Xavier de Charlevoix explicó inmejorablemente las consecuencias territoriales de los tratados de Ryswick (1697) y de Utrecht (1713), así como las del tratado firmado el 8 de septiembre de 1700 entre Nueva Francia y las Naciones Indias. ${ }^{8}$ Y Bruce P. Lenman demostró que ambas guerras constituyeron un todo unitario, desplegado en dos actos sucesivos. ${ }^{9}$ Es en esta singladura coyuntural de medio siglo (1661-1714) como se podrá interpretar cabalmente la «atlantización de las guerras europeas», puesto que en este contexto se desarrollaron las guerras iroquesas, apoyadas por Inglaterra en contra de Francia entre 1682 y 1701. Y otro punto de inflexión básico lo constituyó la conquista inglesa de Nueva Amsterdam, convirtiéndola en Nueva York en 1664. ${ }^{10}$

\section{Fuentes y metodología}

Las tres fuentes básicas para el estudio tanto de Nueva Inglaterra como de Nueva Francia en la encrucijada internacional liderada primero por Francia y después por Inglaterra a partir de los tratados de Utrecht son fundamentalmente las siguientes: 1) los tratados internacionales (informes de embajadores, reunión de plenipotenciarios y tratados propiamente dichos); 2) el Board of Trade de Inglaterra o el Ministere de Marine ou des Colonies de Francia; 3) los gobernadores Generales de Nueva Inglaterra (Andros, Dudley) y Nueva Francia (Frontenac y Vaudreuil); y 4) toda aquella otra documentación relacionada directamente con los pueblos america-

7 Gerard, 1885.

8 Charlevoix, 1744, II, 236-374. Los tres volúmenes. de este libro son fundamentales por su modélica organización formal, por su interesantísimo contenido y por sus magníficas ilustraciones.

9 Lenman, 2001.

10 Beer, 1958; Lenman, 2001a, 272-279. 
nos autóctonos, de los que el Archivo Secreto Vaticano contiene una amplia y detallada información. ${ }^{11}$

El paradigma interpretativo desde el que se han de analizar las cuestiones históricas lo ha puesto de manifiesto, entre otros, J. L. Granatstein: «The task of the current generation is to build on the past, to understand it, and, where necessary, to triumph over it. If we cannot, the fault is not in what happended one, three centuries ago, but in ourselves». ${ }^{12}$ Construir, entender y triunfar, he ahí las tres tareas que se deben desprender de la rigurosa investigación histórica. Así, pues, construir el hecho historiográfico de las relaciones entre Inglaterra y Francia a propósito de América en las últimas décadas del siglo XVII y primeras del XVIII se hace con el fin no sólo de entenderlas, sino también de brindar claves explicativas que permitan afrontar el presente de forma conciliadora. ${ }^{13}$

La historia política que nos interesa aquí, como perspectiva preferente aunque no única, no es naturalmente la historia política decimonónica, positivista y episódica. Por el contrario, entroncando con las líneas de investigación más recientes, esta historia política es una parte esencial de la vida social. Pero en cuanto estructura parcial autónoma, pero configuradora de un orden coercitivo o al menos cohesivo, necesita en su explicitación que se tengan en cuenta tanto los elementos internos propios de la vieja sociedad amerindia y de la nueva sociedad colonial como los factores externos, pero decisivos de las respectivas sociedades metropolitanas. No se ha de olvidar que la historia de América es también la historia de la rivalidad franco-inglesa por la hegemonía mundial en la segunda mitad del siglo XVII y principios del XVIII. Por lo demás, no se hace otra cosa más que aplicar un viejo, pero de gran vigencia actual, pensamiento historiográfico de William John Eccles. La excelente selección de trabajos escritos por este autor durante veinticinco años están organizados en torno a tres grandes temas, estrechamente relacionados entre sí: el imperialismo europeo, las colonias norteamericanas y los pueblos indígenas.

Primarily the essays were, for the most part, an attempt to drag the history of New France out of its narrow, all-confining, parochial context and into three boader streams of history: those of continental North America, European culture and imperialism, and the stream, for too long neglected, of the indigenous peoples. ${ }^{14}$

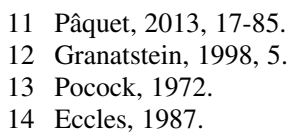


La elaboración de esa nueva historia política depende en gran medida de la óptica que se adopte. Con el utillaje conceptual de Xavier Gil, Carlos José Hernando Sánchez, F. Lorda y Alaiz y José María Mardones; y con los ejemplos historiográficos de Luis González Seara y Michael Mann se aborda la historia política de Euro-América, teniendo en cuenta de modo complementario la lucha por el poder, pero también la lucha contra el poder. Con la primera dimensión se fijan todos los elementos intervinientes en la configuración de la estructura política; y con la segunda se dan cuenta de todas las fuerzas que se mueven en la estructura social. ${ }^{15}$

\section{El poder imperial-metropolitano. Imperios coloniales de Francia e Inglaterra}

Hasta mediados del siglo XVII la hegemonía económica de los Países Bajos en el Atlántico fue indiscutible. ${ }^{16}$ Pero a partir de entonces las cosas cambiaron. La contracción de su comercio en la Europa del Norte hacia 1650-1660, del que dependía su crecimiento; y, sobre todo, las nuevas ambiciones marítimas y coloniales de Francia e Inglaterra, obligaron a los Países Bajos a compartir el botín atlántico. ${ }^{17}$ Según Paul Butel:

the measures taken by England and France to protect their shipping and their trade (the English Navigations Acts of 1651 and 1660, Jean-Baptiste Colbert's tariff-list and ordinances of 1664, 1667 and 1674) had a long-terme effect. Added to this were the consequences of the naval conflicts, in particular those of the first Anglo-Dutch war of 1652-1654, where English seizures of enemy vessels amounted to a minimum of 1,000 ships and enabled the merchant fleet, which until then had been condemned to remain at a relatively low rank, to be rapidly enlarged.

Esta situación se agravó para los Países Bajos con la guerra entre Luis XIV y la República Neerlandesa en 1672. «Their Hansard and English rivals (the former using neutrality from the outset of the conflict, the latterdoing likewise from 1674 rushed to take avantage of their difficulties. The time of the United Provinces'economic hegemony was at end». A finales del siglo XVII el control del Atlántico pasó a manos de Inglaterra, «when

15 Gil Pujol, 1983; González Seara, 1995; Hernando Sánchez, 1997; Lorda, 1988; Mann, 1991, I; Mardones, 1994.

16 Cordova-Bello, 1964; Shomette y Haslach, 1988.

17 Lintvelt, Ouellet y Hermans, 1994; Martínez Shaw y Oliva, 2005. 
it became aware of a commercial revolution based on two principal elements, namely, a spectacular growth in exports to Europe, and the increasing movement of capital, often of foreign (Dutch) origin, necessary to the development of commerce». ${ }^{18}$

\section{Expansión colonial francesa}

Durante el período llamado Régimen Real (1663-1713), el Imperio colonial francés en América se extendió desde Acadia en el Noreste hasta Los Grandes Lagos en el Oeste; y desde la bahía de Hudson en el Norte hasta el Golfo de México en el Sur, sirviendo de unión entre estas dilatadas tierras los larguísimos valles de los ríos San Lorenzo, Ohio y Mississippi. Pero esta vastísima exploración, guarnecida con fortificaciones estratégicas, no implicaba traslado de población, que prácticamente se asentaba en las tres pequeñas comunidades de Québec, Trois-Rivières y Montréal. ${ }^{19}$

Aunque Jolliet y Marquette fueron quienes descubrieron el río Mississippi en junio de 1673, la fascinante hazaña de recorrerlo hasta su desembocadura correspondió a La Salle, Tonty y Hennepin entre 1674 y $1682 .{ }^{20} \mathrm{~A}$ pesar de las permanentes rivalidades franco-inglesas, las inacabables guerras iroquesas y la separación oceánica entre metrópoli y colonia, aquellos amplísimos territorios canadienses estuvieron unidos a la monarquía francesa hasta que en el tratado de Utrecht se comenzó a desmembrar aquel vasto imperio con la devolución de la bahía de Hudson y la cesión de Acadia y Newfoundland a Inglaterra. ${ }^{21}$

No obstante aquella extensión territorial, el genuino gobierno - toma de decisiones - lo ejercía la Corte de Versalles, dejando para las autoridades coloniales la administración o ejecución de aquellas decisiones. La relación entre aquel gobierno de Francia y esta administración de las autoridades coloniales se mantenía a través de exigentes memoranda y detalladas cartas respectivamente. ${ }^{22}$

18 Butel, 1999, 95-96; Several Treaties of Peace and Commerce, 1685. Estos tratados de 1667, 1669, 1670, 1674 y 1676 fueron mandados imprimir por el rey Jacobo II en la corte de Whitehall el 1 de marzo de 1684; firma la orden Sunderland.

19 Graham, 1950, 26.

20 Ibidem, 48.

21 Lanctot, 1964, XIII.

22 Ibidem, 210. 
Según George Durand «l'impératif économique se nommait à l'époque mercantilisme. Cette pratique imposait la surveillance stricte des circuits des monnaies et des biens». ${ }^{23}$ Según esta doctrina mercantilista, la única razón de la existencia de las colonias no era otra que económica: aprovisionar a la metrópoli de las necesarias materias primas y proporcionar mercados para exportar los productos elaborados..$^{24}$ En estas generales coordenadas mercantilistas, la economía de la Nueva Francia experimentó en aquel largo período una expansiva colonización y sólida organización institucional, que va de 1663 a 1713, dos coyunturas muy distintas. La primera, que coincide cronológicamente con la década inicial del Régimen Real (1663-1673) y políticamente con el impulso del ministro Colbert en la metrópoli y del intendente Talon en la colonia, se caracterizó por un fuerte crecimiento económico, gracias a la explotación de los propios recursos naturales de Canadá y a las ayudas de los no menos importantes subsidios reales. ${ }^{25} \mathrm{~A}$ esta política económica expansiva sucede otra de notoria recesión, protagonizada en la colonia por el conde de Frontenac (Louis de Buade), en la que casi todos los esfuerzos económicos se concentraron en los gastos militares, que implicaban las ya continuas guerras anglo-iroquesas. ${ }^{26} \mathrm{La}$ imperiosa necesidad de hombres jóvenes para la guerra continental y los ingentes gastos militares de Luis XIV fueron dos de los grandes obstáculos metropolitanos que dificultaron el desarrollo de Nueva Francia en un momento, en el que la presión expansiva de Nueva Inglaterra era todavía titubeante. Sin una decidida política de emigración y con unos subsidios reales muy menguados, Canadá fue prácticamente abandonada a su suerte, obligada a desarrollarse con sus propios recursos. ${ }^{27}$

En la primavera de 1686 los franceses atacaron los tres puertos de la Compañía inglesa de las Indias (Moose Factory o Saint-Louis, Fort Charles y Albany). Aunque ese mismo año se firmó el tratado de neutralidad entre Luis XIV y Jacobo II (16 de noviembre de1686), poco después se constituyó la Liga de Augsburgo, que desencadenaría la guerra de los Nueve Años contra Francia (del 17 de mayo de 1689 al 20 de septiembre de

23 Durand, 1969, 252.

24 Lanctot, 1964, 197.

25 Eccles, 1998, 66-99.

26 Lanctot, 1964, 217; Lorin, 1985; Parkman, 1897; Eccles, 1959. Las visiones de estos dos últimos autores son contrapuestas: el primero es anglófono y liberal, mientras que el segundo es francófono y absolutista.

27 Lanctot, 1964, 226-227. 
1697). ${ }^{28}$ Esta declaración de guerra de Inglaterra contra Francia en 1689 dejó sentir sus efectos en la colonia francesa casi de inmediato. Al año siguiente, 1690, William Phips (1651-1695) conquistaría Port Royal, poniendo en entredicho los límites que separaban la colonia francesa de Acadia de Nueva Inglaterra. ${ }^{29}$ Durante esta guerra de los Nueve Años (16891697) y la inmediata de Sucesión a la Corona española (1702-1713), la colonia francesa de Canadá, aliada con los indios Abenakis, estuvo constantemente amenazada por una invasión inglesa, que se consumó cuando en 1710 por segunda y definitiva vez los ingleses conquistaron Port Royal. Por el tratado de Utrecht (1713) Acadia, Newfoundland y la bahía de Hudson pasaron definitivamente a poder de los ingleses..$^{30}$

Así, pues, el point tournant de las relaciones internacionales tuvo lugar en 1689, comienzo de la guerra de los Nueve Años. Antes de esta fecha Francia, aliada con Inglaterra, luchaba contra España y los Países Bajos. Después de aquel año, la Liga de Augsburgo, liderada por Inglaterra e integrada por España, el Imperio y los Países Bajos, se coaligó contra el poder hegemónico de la Francia continental. Las vicisitudes de las guerras amerindias, no obstante sus propias motivaciones, hay que estudiarlas a la luz de esta conflagración europea. En los tratados de Ryswick y Utrecht se establecieron los límites territoriales entre Nueva Francia (Canadá) y Nueva Inglaterra, pero los ingleses — además de Acadia — se fueron introduciendo al sur de San Lorenzo en las tierras de los indios Abenaquis. ${ }^{31}$

\section{Expansión colonial inglesa}

Durante este período finisecular Inglaterra consolidó las trece colonias, pero ya puso en marcha la conquista del Oeste traspasando los Apalaches y, sobre todo, disputando constantemente a Francia, con la ayuda de los iroqueses, los territorios canadienses. ${ }^{32}$ En 1670 Carlos II de

28 Traité de Neutralité conclu a Londres le seiziéme Novembre 1686..., 1-12. De este importante tratado, que no se cumple porque estalla la guerra en 1689, merecen destacarse los acuerdos siguientes: utilización conjunta de la isla de San Cristóbal: agua para los franceses y sal para los ingleses; derecho de los franceses de pesca de tortugas en las islas Cayman; respeto y mantenimiento de lo acordado en Breda (1667), según lo cual Acadia pasó a los franceses; y la utopía de que no hubiera guerra en las colonias, aunque la hubiese en las metrópolis.

29 Lanctot, 1964, 227; Baker y Reid, 1998.

30 Pritchard, 2004, 358-401.

31 Parkman, 1983, II, 410-439.

32 Graymont, 1985, 394-426. 
Inglaterra concedió a la Hudson's Bay Company la explotación de todas las tierras drenadas por los ríos que desembocaban en la bahía y estrecho de Hudson. Era ésta una amplísima área territorial, que se extendía hacia el Sureste hasta Dakota del Norte. ${ }^{33}$

Entre 1681 y 1682 se promulga la ley orgánica del imperio inglés. Pero esta constitución imperial hay que encuadrarla en el marco general de una grave amenaza de guerra civil, en la que peligraba la paz del país, la autoridad de la Corona, la unidad de la Iglesia y, desde luego, la constitución de las colonias. En este horizonte delicado estallaron el Popish Plot y la Exclusion Crisis. Los resultados de todos estos zarandeamientos fue lograr un equilibrio entre el «imperio» (control y autoridad de la Corona) y la «autonomía» (importancia de la legislación y de la representación de las provincias o entidades locales)..$^{34}$

Partiendo de la «definición constitucional» de 1681, Webb califica al «imperio» de la siguiente manera: «The essencial element in the definition of empire is the imposition of state control on dependent peoples by force. The instrument of that imposition is the army. There are no empires without armies». ${ }^{35}$ En este proceso de imperio (militar) Webb distingue tres fases, comenzando la primera en Europa los monarcas Tudor. Y en este proceso de militarización y centralización administrativa se consolidó el «gobiernoguarnición» por obra de Marlborough.

The result was that, by 1681 , Anglo-American relations were dominated by an imperial system whose principal agents were the governors-general. These officers of the English army constituted nine-tenths of the royal provincial governors during the adolescence of the old empire, that is, between the Restoration of the monarchy in 1660 and the death of King George I in 1727. The maturation of that empire, in the period 1681 to 1722 , and its key event, the imperial achievement of Marlborough's governors-general, is the subject of this volume's immediate sequel. Here we may only note that, by 1727, garrison government and its development by Marlborough's subordinates, was being overlaid, if not undone, by the commercial and colonial policies long advocated by «country» politicians and whiggish merchants. These policies were at long last effected by the Walpole regime. The renewal of imperial war after 1739, however, ended this era of unsalutary jobbery. Once again, armed authoriy and imperial control were set against commercial motivation and colonial autonomy. «The great war for the empire», between 1754 and 1763, at last achieved the imperial

33 Rich, 1961; Graham, 1950, 52; Hinderaker, 1999. Para este último autor el imperio inglés fue un imperio comercial, un imperio territorial y también un imperio de libertad.

34 Claydon, 2007, 284-313; Armitage, 2000.

35 Webb, 1979, XVII. 
ambitions of two centuries, but at the price of provoking the resistance of the colonial elites and the revenge of imperial rivals that combined as the American Revolution. ${ }^{36}$

Tal vez sea demasiado tajante Webb en afirmar la antinomia absoluta entre los intereses comerciales (yeomen farmers and small planters) de un lado y los intereses imperiales de otro (monarchy and governors-general). Pero esta es su tesis, que se debe tener muy en cuenta.

This Anglo-American conflict was fueled by incompatibility of imperial social and political values with those of capitalism. Imperial ideals glorified monarchy. Individualist economic pursuits fostered oligarchy. The empire reflected the political authority of the king's governors-general, and it gave priority to the social needs of yeomen farmers and small planters. Commercial explotation put political power in the hands of rising merchants and engrossing landlords, and it served their social interests. ${ }^{37}$

En el importante trabajo de David Hancock —elaborado partiendo de las cartas del capitán William Freeman, plantador de azúcar y comerciante de esclavos, que abandonó el Caribe a finales de 1674 o principios de 1675 y se movió por Londres como agente- se demuestran —o tratan de demostrar - dos ideas básicas: 1) hay que estudiar la reciprocidad de relaciones entre los dos lados del Atlántico como un conjunto económico muy unido; y 2) el imperio británico debe su construcción a un unificado grupo administrativo, del que formaban parte individualidades señeras como el capitán citado. Con esta tesis mercantil-individualista se opone a las tesis militaristas de Webb. Esto escribe concretamente Hancock:

In the last few years, a number of historians have proposed alternative developmental explanations that stress the interplay between metropolitan and colonial forces. Chief among their concerns are the role played by agency and mutuality on the one hand and credit and trust on the other hand. Many of these approaches have been styled «Atlantic» [...]. However wide the ambit, Atlantic analysis takes the colonies and colonial development seriously, as seriously as development in the mother country itself, accentuating both inter-imperial exchanges and intra-imperial negotiations, and views the whole as an interactive construction..$^{38}$

Al fijar sus objetivos, que no son otros que demostrar que los asentamientos ingleses persiguieron el desarrollo de una agricultura comercial partiendo del esfuerzo individual y empresarial, Hancock contrasta estas

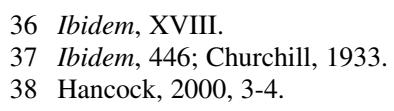


intenciones imperiales de Inglaterra con las que desarrollaban España, basadas en la burocracia y en la extracción minera; y con las de Francia y Holanda, basadas tan sólo en el comercio, al estilo del imperio políticomilitar de Roma. ${ }^{39}$

\section{Inglaterra sustituye a Francia}

A modo de conclusión se podría afirmar que a finales del XVII y principios del XVIII, Inglaterra creció económicamente, Francia —a pesar de su agresiva expansión comercial directa e indirecta en la América Española decreció- ${ }^{40}$ Las causas de este proceso económico fueron tanto interiores como exteriores. Las guerras civiles y luchas internas a lo largo del XVII afectaron más negativamente a Francia que a Inglaterra. Y desde la perspectiva exterior, Inglaterra dio pasos lentos pero decisivos para asegurar una progresiva hegemonía marítima y comercial. En primer lugar están las guerras victoriosas contra Holanda entre 1652 y 1674; después el beneficioso tratado con Portugal de 1703, que le permitió introducirse en Brasil cambiando productos manufacturados por oro; ${ }^{41} \mathrm{y}$, finalmente, el tratado de Utrecht de 1713, en el que logró de España el asiento de negros (la provisión de negros a América española pasaba a manos de los comerciantesesclavistas ingleses) y el navío de permiso («annual ship»), en el que se desplazaban a América (Porto Bello y Vera Cruz) cada año 300 toneladas de productos ingleses; además de las importantísimas anexiones territoriales (Gibraltar, Newfoundland, etc.). Escribe Paul Butel:

English colonial expansion was precocious and during the 1660s the re-exportation of the exotic products constitued the principal factor in the growth of overseas trade, whereas France'colonies and her colonial trade remained negligible for a long time. In 1715 the English merchant fleet was more important, and the accumulation of commercial capital proportionally higher, as was trade. ${ }^{42}$

El poderío marítimo le permitió a Inglaterra controlar el comercio en el Norte de Europa y en al Atlántico. Cuando a finales del XVII y principios del XVIII las guerras del Norte dificultaron la provisión de madera,

\footnotetext{
39 Lounsbury, 1969.

40 Frostin, 1971, 326.

41 Francis, 1966.

42 Butel, 1999, 151.
} 
cáñamo, alquitrán y hierro («naval munitions»), se aprovisionaron de gran parte de estos productos en sus colonias americanas. «The means for this domination (in the sea) — reitera Butel— were provided by the commercial mastery of both the markets of northern Europe, where England successfully challenged the Dutch, but could not remove them altogether, and on other side of the Atlantic». ${ }^{43}$

\section{El poder autóctono-amerindio}

\section{Los pueblos aborígenes de Nueva Francia}

Uno de los núcleos más importantes de población aborigen estuvo constituido por «Los Indios de las Cinco Naciones»: los Mohawks, Senecas, Oneidas, Onondagas y Cayugas. ${ }^{44}$ Estos amerindios, que formaron entre sí la confederación de los Iroqueses, se opusieron prácticamente sin tregua por todos los medios e, incluso, con la ayuda de los ingleses, a la expansión y asentamiento de los colonos franceses. ${ }^{45}$

Estudios importantes sobre el poblamiento aborigen se deben a Dickason y a Bumsted. ${ }^{46}$ Entre los pueblos aborígenes había grandes diferencias, aunque estuvieran agrupados en «Las Cinco Naciones». ${ }^{47}$ La tesis doctoral de François Larose, defendida en la Universidad de Québec en Montréal, ha puesto de relieve las consecuencias de la ocupación de las tierras de iroqueses y algonquians por los franceses. ${ }^{48}$ Uno de los capítulos más importantes de la historia de Nueva Francia fue la casi permanente guerra con los indios Iroqueses, al menos desde 1682 hasta $1701 .{ }^{49}$ En la clásica historia escrita a mediados del siglo pasado por Etienne Michel Faillon se le concede a este sangriento e irreductible conflicto una transcendencia decisiva para la comprensión de los avatares acaecidos a la colonia francesa. Aunque no se compartan las ideas del autor por sus prejuicios decimonónicos y de militancia católica en relación con los «salvajes», es indudable que

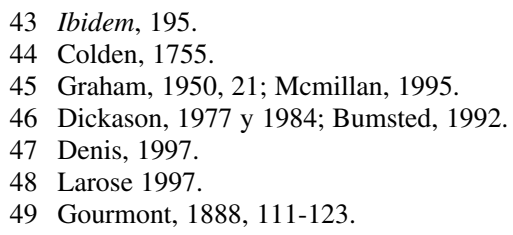


el asentamiento de los colonos fue especialmente duro y estuvo permanentemente amenazado desde el interior del país por los propios nativos, que defendían palmo a palmo sus tierras, sus intereses económicos — facilitados muchas veces por los ingleses-y su propio modo de vivir..$^{50}$

Es innegable que veinte años de ininterrumpida guerra franco-iroquesa -1682-1701 - causaron terribles estragos tanto en vidas humanas como en gastos militares. A la lucha por la tierra y por los recursos económicos que ésta representaba, hay que añadir el antagonismo de culturas irreductibles y de modos de vida muy distintos. Las graves consecuencias negativas que se pueden derivar de ciertas interpretaciones historiográficas las ilustra de modo fundado Patrice Groulx en su trabajo sobre Dollard des Ormeaux. Este acontecimiento de 1660, que enfrentó a franceses y aliados contra los iroqueses, se convirtió en un «mito» por obra y gracia de la ideologización del hecho histórico. Es la revisión del hecho historiográfico -Faillon, Parkman, Lanctot, etc.- - el que es especialmente analizado por la autora para presentar las diversas $y$, a veces contrarias, interpretaciones de un mismo hecho, según los vientos ideológicos que corren en cada uno de los sucesivos presentes. ${ }^{51}$

El estudio de las cinco «reducciones» del valle de Saint-Laurent, mantenidas por los jesuitas según el modelo de las ya existentes en Paraguay, no sólo tuvo un interés religioso de cristianizar a los indios preservándoles de la «contaminación» externa, sino que sirvieron también como importantes bastiones de defensa, utilizados muy beneficiosamente por los franceses contra las frecuentes invasiones iroquesas e inglesas. ${ }^{52}$ Después de firmado el tratado de Ryswick en 1697 entre Francia y la Liga de Augsburgo, los ingleses americanos dejaron de hostigar a los iroqueses contra los franceses canadienses. La paz, por fin, era posible. Ésta se firmó en $1701 .{ }^{53} \mathrm{Se}$ puede afirmar genéricamente que la sociedad francesa rechazó la fusión con los nativos y éstos, a su vez, tampoco toleraron la asimilación. Este irreconciliable antagonismo social, que si bien es cierto no dificultó la estrecha colaboración y, desde luego, el comercio con algunos grupos de indios (hurones), hizo que, andando el tiempo, la raza blanca canadiense se mantuviese pura y homogénea en su descendencia no mestiza. ${ }^{54}$

50 Faillon, 1865, III, 119-158.

51 Groulx, 1998.

52 Jetten, 1994; Jones, 1986.

53 Wallace, 1957.

54 Lanctot, 1964, 205. 


\section{Los pueblos aborígenes de Nueva Inglaterra}

Sobre la población aborigen las epidemias — smallpox (viruela) y measles (sarampión) — fueron más nefastas que las guerras. ${ }^{55}$ Antes de la conquista, Norteamérica (al Norte de Río Grande) tenía más de dos millones de habitantes, de los cuales la más alta densidad estaba en las costas del Pacífico. En el XVII Quebec no tenía más que 100.000 habitantes y Nueva Inglaterra no sobrepasaba los 30.000. ${ }^{56}$ Para Butel la colonización francesa e inglesa fueron diferentes. La primera fue más integradora. Colbert y su intendente Talon pretendían que en Canadá sólo hubiese un «solo pueblo y una sola sangre» («one peple and one blood»). A pesar de estas buenas intenciones las epidemias, los enfrentamientos con los iroqueses y con todas las tribus aliadas de los ingleses diezmaron la población amerindia. Los ingleses, por su parte, desde un principio fueron más agresivos, porque necesitaban tierras y pieles:

The attitude of the English colonists was even more aggresive: since the very beginning of colonization they had needed more land and more furs. In New England and Virginia, the murderous Indian wars of 1630-1640 and 1670 became wars of extermination. ${ }^{57}$

La nación Algonquin fue la primera en habitar Nueva Inglaterra. Eran indios de los bosques, que cultivaban la tierra, cazaban, pescaban y acampaban a lo largo de la costa. El grupo más numeroso de los Narragansett, una tribu de Rhode Island, fue prácticamente aniquilado por los colonizadores ingleses in the Great Swamp Fight durante la guerra del Rey Felipe (King Philip's War). La tribu Pequot de Connecticut fue diezmada por los colonizadores y tribus enemigas en la guerra Pequot de 1637. En la actualidad los indios Pequot Mashantucket poseen exitosas empresas cerca de Mystic (Connecticut). ${ }^{58}$ El 19 de diciembre de 1675, durante el Great Swamp Fight (en Mt. Hope), los colonizadores ingleses lanzaron un ataque sorpresa contra los indios Narragansetts, la más poderosa tribu de Rhode Isaland. Esto tenía lugar en el contexto de la guerra del Rey Felipe (King Philip's War) entre 1675 y 1676, en la que Felipe, jefe de los indios Wampanoags,

55 Wilbur, 1978, 47-49 y 74.

56 Biraben, 1966, 112.

57 Butel, 1999, 173. El autor denomina este apartado con el significativo epígrafe de «The destruction of the Amerindians».

58 Hauptmann y Wherry, 1990. 
condujo a su tribu, juntamente con los indios Narragansetts y Nipmucks contra los colonizadores ingleses. ${ }^{59}$ Esta guerra anuló la fuerza y redujo la población de los indios. A partir de ahora (1676), y con la amarga experiencia de la rebelión de Bacon y de la guerra del Rey Felipe, el poder metropolitano inglés ejercerá un fuerte control sobre todos los asuntos coloniales. ${ }^{60}$

Una de las más graves consecuencias de la guerra del Rey Felipe, en la que murieron 5.000 indios y 2.500 ingleses, fue la división entre razas opuestas. A partir de entonces los indios eran «los otros». Esto lo pone de manifiesto Edmund Browne, un ministro de Sudbury (Massachusetts), que escribe informes sobre el particular a las autoridades advirtiéndoles del peligro constante que son los indios. Esto dice Jenny H. Pulsipher: «That calamity cost the lives of nearly 5,000 Indians and 2,500 English and led to the destruction and abandonment of more than a dozen English towns, most, like Sudbury, on the frontier». ${ }^{61} \mathrm{Y}$ termina el trabajo, matizando:

One century after the conclusion of King Philip's War, the racial divide between English and Indians was substantial. Whereas tensions between the two peoples in Massachusetts had always been present, the war was pivotal in the development of race as a dividin line. The beginnings of that process are evident in Browne's letter and in the legislation proposed and adopted in the decade following King Philip's War. During the next century, such attitudes and acts sealed the Indians'status as racial «others» in their own land. ${ }^{62}$

En el crucial año de 1676 las colonias americanas se transformaron, según Webb, en provincias inglesas. La autonomía de las colonias fue sustituida por el control de la metrópoli a través del gobernador-general, ampliando el modelo de Jamaica y de Nueva York, la propiedad personal del líder imperialista inglés James, duque de York. ${ }^{63}$ En aquel año de 1676 se fraguó una auténtica revolución imperial. Ésta es la conclusion de Webb:

The Imperial Revolution altered the shape of American institutions; it redirected the course of colonial growth; it made autonomous colonial politics Anglo-American. Economic and social exchanges, as well as political culture, were anglicized in the wake of the crown's «forcible substitution» of royal rule for that of colonial oligarchs. American colonies thus became English provinces. The imperially instituted diplomatic union of the Anglo-American provinces encouraged even the most imperious

59 Schultz y Tougias, 2000.

60 Webb, 1984; Arneil, 1998, 168-171.

61 Pulsipher, 2001, 431.

62 Ibidem, 441.

63 Webb, 1984, XV. 
Amerindians to become serviceable allies of «the Great King Charles over the great Lake». These alterations in America transformed Whitehall's view of the world. Now Eastern America was seen as a whole, with its political, diplomatic, strategic center not, as formerly, at Boston or at Jamestown, the capitals of the old colonial cultures, but, rather, at the headquarters of England's continental empire in America, Fort James, New York. The three revolutions of 1676 had ended American independence. ${ }^{64}$

$\mathrm{El}$ «Covenant Chain» de 1677 establece la paz entre los amerindios y las colonias británicas y fija los límites territoriales de las respectivas influencias hasta 1768. En esta última fecha los ingleses se adueñan de todo el imperio iroqués. La consolidación del imperio inglés en América pasaba por la alianza con los iroqueses, permitiéndole con ello enfrentarse a los franceses, someter a los holandeses, controlar a las republicanas colonias de Nueva Inglaterra y Delaware. Según Webb ésta fue la obra del gobernador Andros:

Edmund Andros' parallel career was premised upon the rise of England to European military prominence and the consequent expansion of its Atlantic empire. He first encountered Indians and fought the French in defence of England's staple-crop colonies in the West Indies. Then Andros was ordered to garrison and govern conquered New York on behalf of that eminent imperialist the duke of York, and as part of the rising English empire's deprivation of the Dutch. Andros' career was not just a consequence of European imperial rivalries; his instructions were premised upon English recognition that the fledgling province of New York was an apt instrument by which to extend imperial authority on the American continent. Yet Andros quickly saw that his ability to defy the French, coerce New England, subdue the Dutch, and defined Delaware all depended upon conciliating the Iroquois, a fact not hitherto appreciated at Whitehall. ${ }^{65}$

\section{El poder colonial-señorial}

\section{La configuración político-económica y socio-cultural de Nueva Francia}

A George Durand se debe esta lapidaria y certera frase: «Distance, ignorance, indifférence, tout tendait à livrer les colonies à leur propre destin. L'imperialisme n'a peut-être été qu'une démission de l'État». ${ }^{66} \mathrm{Si}$ es

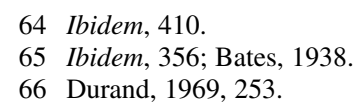


indudable que la colonia francesa disfrutó en la práctica de la vida política diaria de una gran autonomía, es muy oportuno recordar aquí el acertado juicio historiográfico de Louise Dechêne, quien escribe estas enjundiosas palabras: «dans une perspective de longue durée ce ne sont pas les compagnies métropolitaines qui comptent, mais l'organisation locale, qui engendre une société nouvelle». Ahora bien, mientras que a Duchêne le interesó de esta «organización local» preferentemente el señorío, la familia y la parroquia, aquí nos vamos a centrar en la «organización política local», sin ignorar naturalmente la importancia de aquellas tres instituciones socioeconómicas estudiadas tan magistralmente por la autora en los ricos protocolos notariales de Montréal. ${ }^{67}$ La Compañía de Nueva Francia o de los Cien Asociados - Compagnie de la Nouvelle-France ou des Cent Associés- fue fundada por Richelieu en 1627. Esta colonia de explotación y poblamiento duró hasta 1663, fecha en la que Colbert sustituyó aquella dominación indirecta de la Compañía por la administración directa de instituciones coloniales, que, al reproducir el esquema orgánico de la metrópoli, convertían a aquellos territorios del hinterland del San Lorenzo en una «provincia de ultramar». ${ }^{68}$

El gobernador fue el auténtico representante del rey y, por lo tanto, el responsable de mantener la soberanía francesa en aquellos territorios ultramarinos. ${ }^{69}$ Aunque sus competencias abarcaban muchos campos, la que más le distinguía era la exclusiva jurisdicción en los asuntos militares (fortificaciones, guerra y paz). En los tres distritos de Québec, Montréal y TroisRivières había otros tantos gobernadores locales, asumiendo el primero la potestad suprema con el título de gobernador general..$^{70}$ No se puede hablar de este período sin mencionar a Louis de Buade, conde de Frontenac, que gobernó Nueva Francia en dos momentos cruciales para la colonia: ambos períodos abarcaron dos décadas, desde 1672 a 1682 la primera; y entre 1689 y 1698 la segunda. En estos veinte años de gobierno férreo de Frontenac se consolidó el Régimen Real, a pesar de los casi insuperables obstáculos de las guerras iroquesas, el hostigamiento inglés de la última década y los problemas internos que, por su carácter dictatorial, tuvo con el obispo Laval, el intendente Duchesneaux y el propio Consejo Soberano. ${ }^{71}$

67 Dechêne, 1988, 10.

68 Durand, 1969, 254.

69 Nassiet, 1997, 20-50.

70 Lanctot, 1964, 211.

71 Graham, 1950, 40-41. 
El régimen señorial canadiense - histórico esquema feudal de tenencia de la tierra- hunde sus raíces en 1598, cuando se autorizó al lugarteniente general, Sieur de la Roche, establecer una jerarquía entre los propietarios de la tierra. Pero fue con la llegada del intendente Talon, brazo derecho de Colbert en la colonia, cuando realmente se desarrolló. ${ }^{72}$ Independientemente de su significación económica, que no era desdeñable, el régimen señorial trasladado a Nueva Francia tuvo una dimensión social muy importante, en la medida en que los que ostentaban los títulos de propiedad eran también los que ocupaban los primeros puestos de una sociedad piramidal. ${ }^{73} \mathrm{Si}$ la agricultura y la ganadería fueron ganando terreno al bosque, al menos en la ribera del gran río San Lorenzo, este proporcionó también una abundante pesca. Las anguilas bajaban del lago Ontario; y el salmón, el arenque, el bacalao, las focas y las marsopas subían desde el Golfo hasta la Malbahía. ${ }^{74}$

Dada la abundancia de madera en los bosques canadienses, el intendente Talon creó importantes aserraderos de madera y astilleros de construcción de barcos. La mayor parte de estos barcos eran vendidos a los navieros franceses, quienes los empleaban para el comercio entre Canadá, Francia y las Antillas. La vieja idea de Colbert de hacer mástiles a gran escala con la madera de los bosques canadienses fue puesta en práctica en 1686 por el comerciante François Hazeur, quien se asoció con Champigny para explotar esta rentable empresa maderera. ${ }^{75}$ En materiales de construcción la colonia fue autosuficiente. Existían abundantes canteras de piedra caliza, que era tratada en los dos hornos de cal de Montreal y en el de Pointe-Lévis. La arena se localizaba en cualquier parte. Pero el ladrillo no se fabricaría hasta más tarde. ${ }^{76}$

Sin duda alguna, el comercio de las pieles, procedente de Tadoussac, de la bahía de Hudson y de las regiones occidentales, fue el más importante tanto por su volumen como por los beneficios obtenidos. Este voluminoso y beneficioso comercio se mantuvo boyante a lo largo de aquellos cincuenta años, a pesar de dos graves obstáculos. Uno fue el contrabando, que era imposible de extirpar por la inmensidad del terreno y los fuertes intereses de muchos particulares. Y el otro, no menos perjudicial, se debió a que los

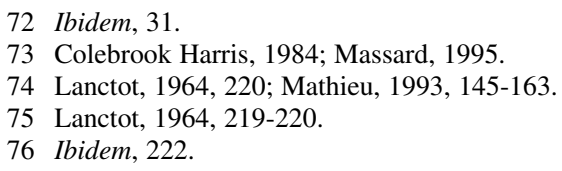


indios preferían llevar las pieles de castor a Albany, en donde los ingleses les pagaban precios más elevados y les vendían los productos más baratos, incluidas naturalmente las bebidas alcohólicas. Esta vieja lucha comercial fue uno de los permanentes frentes que opusieron a franceses e ingleses en aquellas tierras canadienses, que se disputaban palmo a palmo en los primeros momentos de febril asentamiento colonial. ${ }^{77}$ Hasta tal punto fue importante este comercio de las pieles que para William John Eccles constituía una genuina frontera, que se intentaba preservar por todos los medios posibles, incluidos naturalmente los militares. ${ }^{78}$ Hablando de este importantísimo comercio de las pieles no se puede silenciar el trabajo e, incluso, la vida aventurera y libre, de los «corredores del bosque» (coureurs de bois ou boyageurs). A aquellos hombres, curtidos en las llanuras sin horizonte tangible, no les arredraban las amenazas de palizas y mucho menos la condena a galeras. Su vida, que giraba en torno a aquel provechoso comercio de las pieles, consistía en la libertad de hacer y pensar al margen de toda ley y organización social. Aunque menos importante que el anterior comercio de las pieles, el comercio triangular entre Canadá, Francia y las Antillas, además de crear un circuito económico excepcionalmente ventajoso para las tres partes, movilizaba el capital. Canadá exportó trigo, harina, vegetales, pescado, madera, petróleo, bacalao, anguilas, salmón, mantequilla, queso y huevos. De Francia se traía el vino, vestidos, productos de ferretería y comestibles. Y de la Martinica y Santo Domingo salían el azúcar y el ron. ${ }^{79}$

Uno de los temas más ampliamente tratados por la historiografía -Bruce Trigger, Karen Anderson, William Eccles, J. Baird Callicott y Francis Parkman - fue y es el de la identificación de los «salvajes» iroqueses y algonquianos con el diablo por parte de los colonizadores en general y de los jesuitas en particular. Peter A. Goddard explica, utilizando entre otras fuentes las Jesuit Relations (1632-1672) y comparando la acción de éstos con la de los misioneros de la península ibérica, las razones de esta demonización generalizada, que hunde sus raíces en una arraigada tradición dualística o maniquea del pensamiento occidental, pero insiste también en las particularidades de las misiones de los jesuitas en Nueva Francia, muy diferentes a las que tenían lugar en la América luso-hispánica. Escribe Goddard:

77 Merwick, 2002, 188-219; Innis, 1962.

78 Eccles, 1983, cap. 6. ${ }^{\circ}$ : «The Fur Trade Frontier, 1663-1700».

79 Lanctot, 1964, 223. 
The position of missionaries in New France itself also contributed to the shift from credulity to scepticism. In New Spain, the church enjoyed a position a great authority. The Conquista involved the clear superimposition of Iberian social hierarchy; the clergy were a «first estate»' in Mexico or Peru as in Castile. Their «spitual conquest» entailed privilege as well as responsibility. In contrast, New France supported a modest number of missionaries (three in 1632, only fifty or so by mid-century), tenuous habitation, total absence of conquest, and only a limited superimposition of France on native society. In 1634 Paul Le Jeune wrote wistfully of the «great show of power» by the Portuguese in the West Indies.This display had so intimidated aboriginal peoples that they «embraced, without any contradiction, the belief of those whom they admired». In New France, in contrast, missionaries were hostages of the fur trade and of military alliance: they could not assume dominion. Canada was notable for its phisical, social, and spiritual isolation, and for the vulnerability of its settlements. ${ }^{80}$

Sin entrar a discutir estos razonamientos, en principio bien formulados, no hay que olvidarse de que la fuerza de la Iglesia en Nueva Francia era considerable. ${ }^{81}$ El obispo y todo lo que significaba era una pieza esencial en el entramado orgánico de la vida política canadiense. Se produjo una impresionante aculturación. El mestizaje, que apenas se dio, dificultó muchísimo este proceso. Pero en cualquier caso, la cohabitación, no siempre convivencia, posibilitó la formación de nuevos valores en un sentido integrador ${ }^{82}$ Podíamos concluir asumiendo la tesis de Colin G. Calloway, para quien, centrándose fundamentalmente en lo que posteriormente serían los Estados Unidos de América, afirma que la activa relación entre los pueblos amerindios y europeos desembocó en «nuevos países» diferentes tanto para los indios aborígenes como para los inmigrantes europeos. ${ }^{83}$

\section{La configuración político-económica y socio-cultural de Nueva Inglaterra}

Richard S. Dunn distingue cuatro períodos historiográficos: el primero abre la centuria de 1600 y la protagoniza Richard Hakluyt. El segundo período va desde 1607 hasta 1660, es el período de los asentamientos. Los historiadores de este período son Smith, Bradfort, Winthrop y Johnson. El tercer periodo engloba al segundo asentamiento y se extiende desde 1660

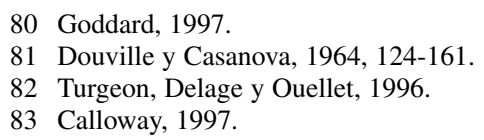


hasta 1680. Aquí los historiadores son Nathaniel Morton, William Hubbard e Increase Mather. A este período pertenecen también John Ogilby, Richard Blome, Nathaniel Crouch ${ }^{84} \mathrm{El}$ cuarto período cierra la centuria, hasta 1708 , y aquí hay que destacar a Cotton Mather (MA), Robert Beberley (Virginia) y John Oldmixon (Inglaterra). ${ }^{85}$

Frente a un gobierno tradicional, de más de 50 años, organizado según los postulados de las «cartas» (charters), se va imponiendo en un proceso largo, que se extendió desde 1676 hasta 1688, un gobierno «imperial», militar. Los fechas claves son 1675 (guerras indias y revoluciones de colonos), 1681 (definición constitucional del Imperio), 1685 (gobierno por comisión de Edmund Andros, 1637-1714) y 1688 (revuelta de Nueva Inglaterra contra Andros coincidiendo con la Revolución Gloriosa). ${ }^{86}$ Una de las instituciones básicas del poder colonial son los gobernadores. ${ }^{87}$ Ellos representaron la autoridad del rey y sus funciones eran preferentemente militares. ${ }^{88}$ Una monografía modélica podía ser la del gobernador de Virginia durante la Revolución Gloriosa, Francis Howard, escrita por Billings. ${ }^{89}$ En la organización del poder colonial, como en toda organización política, había que solventar dos problemas fundamentales: el de la ley y el de la representación. Por la primera se buscaba un marco normativo que obligara a todos; por la segunda se deseaba tener unas autoridades legítimas, que asumiesen las necesidades de la comunidad..$^{90}$ En este sentido, según el cual se perseguía establecer una adecuada relación entre gobernantes y gobernados, entre autoridad y obediencia, Cook trata de explicar la estructura de la comunidad en Nueva Inglaterra durante el siglo XVIII forjada bajo la dirección de los líderes locales. ${ }^{91}$ Los problemas de la ley son tratados de manera general en una obra colectiva dirigida por Pencak y Wright para la colonia de Nueva York; $;{ }^{22}$ y por Mann al estudiar las transformaciones de la comunidad puritana en una individualista sociedad yankee en Connecticut. ${ }^{93}$ Las sensibles cuestiones de la representación política

84 Crouch, 1685.

85 Mather, 1702; Oldmixon, 1708; Dunn, 1959.

86 Records of the Particulier Court of the colony of Connecticut..., 1935, 1; Whitmore, 1968, III, V-XLVI; Newell, 1998.

87 Raimo, 1980.

88 Webb, 1979.

89 Billings, 1991; Henige, 1970.

90 Force, 1846, IV, N. ${ }^{\circ} 9,51-58 ;$ y N. ${ }^{\circ} 11,3-7$.

91 Cook, 1976.

92 Pencak y Wright, 1988

93 Mann, 1987. 
o popular son abordadas por Morgan de manera general (oposición al derecho divino de los reyes, elecciones locales, etc.) $;{ }^{94}$ y por Jordan en el caso concreto de Maryland..$^{95}$ La distinta naturaleza política de los gobernados es analizada por Bushman, que divide la colonia de la bahía de Massachusetts en dos grupos: el más pequeño está sometido a la autoridad real y el otro, más grande, está asociado como pueblo independiente. ${ }^{96}$ Nobles señala diferencias también en esa única relación entre la política y la sociedad en el siglo XVII para el condado de Hampshire. ${ }^{97}$ La organización política de las colonias americanas es tratado de manera conspicua por Bernard Bailyn en un trabajo fundamental. ${ }^{98}$

Sobre la transformación del gobierno de Nueva Inglaterra a raíz de los acontecimientos de 1676, que supusieron la supresión de la autonomía de la Massachusetts Bay Company, controlada por los puritanos (autonomía colonial), por un gobierno colonial fuerte y militar, que a su vez supuso la «anglicización» de las colonias (provincias inglesas), es puesto de manifiesto por Webb de la siguiente manera:

But this praise for the hard-pressed planters re-emphasized courtly and metropolitan contempt for the military inadequacy of their colonial governments, especially the predominant puritan corporation, the Massachusetts Bay Company. The resulting imperial impetus to English intervention produced, first, the elimination of the puritan commonwealths by the short-lived Dominion of New England and then the permanent Anglicization of the New England society and culture. The unlikely instruments of both processes were introduced to metropolitan opinion by the press in 1676: Edmund Andros, governor-general of the ducal dominions called «New York», and his Iroquoian allies, called the «Mohawk». Andros and the Iroquois, the king and his council, all expressed a jaundiced view of New England's territorial ambitions, its mealy-mouthed leaders, and its oligarchical institutions. ${ }^{99}$

En 1700 la población colonial de las Trece Colonias continentales excedía los 250.000 habitantes. Y su crecimiento fue enorme a lo largo del XVIII. En 1659 la población canadiense alcanzaba 2.000 habitantes; mientras que New England pasaba de 32.000 habitantes y las colonias de Chesapeake superaban los 24.000 habitantes. En 1713 la población canadiense

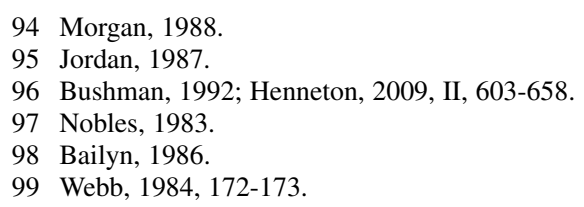


sólo llegaba a los 20.000 habitantes. En este incremento natural —nacidos por matrimonio- jugó un papel fundamental la llegada del regimiento de Carignan Sallières con 400 soldados..$^{100}$

Para McCusker y Menard la economía en general de las colonias británicas tiene tres características fundamentales. La primera es que la economía colonial no se puede entender si no es en el contexto de la economía atlántica. La segunda es la diversidad de la economía colonial. Y en tercer lugar la prosperidad, al menos en el XVIII, de esa economía colonial. Interrelación, diversidad y prosperidad fueron, por lo tanto, los signos distintivos de la economía colonial británica. ${ }^{101} \mathrm{El}$ relevante papel económico de los mercaderes coloniales, así como la importancia de la construcción de barcos en Nueva Inglaterra la han estudiado en profundidad Bernard Bailyn y Nuala Zahedieh. ${ }^{102}$ Para Greene la construcción intelectual de América fue hecha bajo la indudable influencia de la cultura británica. Es la teoría del «excepcionalismo americano». ${ }^{103}$ Para Fischer es indudable la existencia de cuatro culturas regionales en las colonias británicas, que se fueron formando con la llegada de otras tantas oleadas migratorias. A saber, la cultura regional de Massachusetts (emigración de 1629-1640) con proyección a toda Nueva Inglaterra; la de Virginia (emigración de 1640-1675) con la inclusión de toda la Norteamérica Media; la del valle de Delaware (emigración de 1675-1725) con la expansión hacia el sur costero; y la de Southern Backcountry (emigración de 1717-1775) con la incorporación de las tierras altas del Sur. ${ }^{104}$ Ampliando esta visión de Fischer de «región cultural», Meinig, sin olvidar la indudable herencia metropolitana, añade juiciosamente otros condicionantes culturales fundamentales, cuales son el distinto entorno ambiental (geofísico y climático), las diferencias poblacionales de los amerindios, africanos y europeos no británicos y la diversa disponibilidad de recursos materiales. Todo ello, no sólo diferencia a unas culturas de las otras entre las mismas colonias (Nueva Inglaterra, valle de San Lorenzo, bahía de Hudson, valle del río Hudson, Pennsylvania, Virginia, islas tropicales, las Carolinas, Florida, Luisiana, Tejas y el valle del Río Grande), sino que se distinguen todas ellas en conjunto de la cultura metropolitana inglesa. ${ }^{105}$

100 Butel, 1999, 174.

101 Papers relating to an Act of the Assembly of the Province of New York..., 1724; McCusker y Menard, 1985.

102 Bailyn, 1955 y 1959; Zahedieh, 2010, 55-136.

103 Greene, 1993.

104 Fischer, 1989.

105 Meinig, 1986. 
Sobre el puritanismo americano en general y de manera muy particular en Nueva Inglaterra se dispone de numerosas e importantes obras. El primer estudio en profundidad se debe a Perry Miller. ${ }^{106}$ Otras obras ulteriores son menos monolíticas, abriéndose a otros factores condicionantes del espíritu religioso de aquellos primeros colonizadores. ${ }^{107} \mathrm{Si}$ es indudable que los aspectos religiosos son básicos para la comprensión de la cultura en Nueva Inglaterra, los aspectos de lo mágico y de la brujería también estuvieron presentes en la configuración de aquellas mentalidades del Nuevo Mundo. ${ }^{108}$ Para Cohen la afición actual por la literatura de crímenes hunde sus raíces en la época colonial, en que se cultiva ampliamente este género como elemento intelectual básico de la cultura popular. ${ }^{109} \mathrm{El}$ extraordinario desarrollo de la historia criminal en el período colonial lo pone bien de manifiesto Cahn. ${ }^{110}$ Según Cressy las ideas, la familia y la moneda eran los tres vínculos que unían estrechísimamente a Nueva Inglaterra con Inglaterra. ${ }^{111} \mathrm{El}$ gran historiador de las colonias británicas, Bernard Bailyn, ha escrito páginas de obligada consulta sobre la educación y la formación en la sociedad americana. ${ }^{112}$

\section{Conclusiones}

En toda organización política lo que importa es saber quién toma las decisiones, por qué y cómo. Por eso las biografías (sociología histórica), historiográficamente hablando, son tan importantes como los mismos procesos (políticos, económicos, sociales y culturales). Aquéllas orientan o mediatizan a éstos; y los procesos, a su vez, condicionan las biografías.

Además de esta dialéctica de biografías/procesos, ampliamente constatada en las páginas anteriores, se han podido observar otras dos cuestiones bipolares y complementarias, cuales son centro/periferia y unidad/diversidad. La primera ha sido bien estudiada por Inmanuel Wallerstein y, en nuestro caso concreto, por Jack P. Greene. ${ }^{113}$ Para ambos

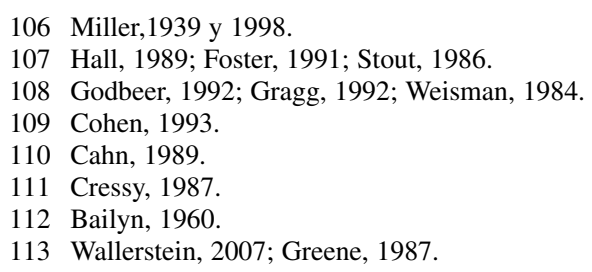


autores el centro del poder político — de la toma de decisiones- cambia constantemente, de ahí que su interrelación - hegemónica o independiente- sea imprescindible tenerla en cuenta en el análisis de la estructura y dinámica de un poder concreto, sea el metropolitano, el amerindio o el colonial. La segunda cuestión es la que relaciona la unidad con la diversidad. Según Edgar Morin se ha confundido siempre la unidad del «hacer» político con la «diversidad» incuestionable de cada pueblo, sea inglés o francés, amerindio o colonial. ${ }^{114} \mathrm{Y}$, lo que todavía ha sido peor, es que ni siquiera hubo unidad en el «hacer» político, porque mientras unos perseguían fines estrictamente económicos, otros le daban preferencia a los socio-culturales.

Y, como telón de fondo, de todas estas conclusiones parciales, aunque complementarias, se ha demostrado la teoría interpretativa de Kennedy, Duroselle y Chauprade, según la cual, con las matizaciones pertinentes, todo imperio (político, territorial, etc.) crece primero y poco después decae. ${ }^{115}$ En nuestro caso, de ahí la importancia del análisis de un tiempo medio o coyuntural, los tratados de Utrecht de 1713 supusieron el hundimiento total de la monarquía hispánica, la caída parcial de la monarquía francesa y la aparición del imperio británico. Por lo tanto, el mejor testimonio del auge de Inglaterra a costa de Francia se ha reflejado de manera fehaciente en la América del Norte, que pasó de ser francesa a convertirse en la plataforma imperial del Reino Unido entre 1697 y 1713.

Recibido el 2 de junio 2014 Aceptado el 4 de febrero de 2015

\section{Fuentes y Bibliografía}

Armitage, David: «Making the Empire British: Scotland in the Atlantic World, 1542-1707», Past and Present. A Journal of Historical Studies, 155, 1997, 34-63.

Armitage, David: «Greater Britain: A useful category of historical analysis?», American Historical Review, 104, 1999, 427-445.

Armitage, David: The Ideological Origins of the British Empire, Cambridge, Cambridge University Press, 2000.

114 Pisani, 1998.

115 Kennedy, 1990; Duroselle, 1992; Chauprade, 2007. 
Arneil, Barbara: John Locke and America. The Defence of English Colonialism, Oxford, Clarendon Press, 1998.

Bailyn, Bernard: The New England Merchants in the Seventeenth-Century, Cambridge, Harvard University Press, 1955.

Bailyn, Bernard: Education and Forming of American Society: Needs and Opportunities for Study, Chapel Hill, Norton, 1960.

Bailyn, Bernard: The Origins of American Politics, New York, Random House, Inc., 1986.

Bailyn, Bernard: «The Idea of Atlantic History», Itinerario, 20, 1996, 1-27.

Bailyn, Bernard y Bailyn, Lotte: Massachusetts Shipping, 1697-1714: A Statistical Study, Cambridge, Harvard University Press, 1959.

Baker, Emerson W. y Reid, John: The New England Knight. Sir William Phips, 1651-1695, Toronto, University of Toronto Press, 1998.

Bates, Albert C.: «Expedition of Sir Edmund Andros to Connecticut in 1687», Proceedings of the American Antiquariam Society, XXXXVIII, 2, Worcester, MA, 1938, 276-299.

Beer, George Louis: The Old Colonial System, 1660-1754, Gloucester, MA, Peter Smith, 1958, 2 vols.

Billings, W. M.: Virginia's Viceroy. Their Majesties' Governor General. Francis Howard, Baron Howard of Effingham, Fairfax, VA, 1991.

Biraben, J. N.: «Le peuplement du Canada français», Annales de Démographie Historique, Paris, 1966,105-138.

Bumsted, J. M.: The peoples of Canada. A pre-confederation history, Toronto, Oxford University Press, 1992.

Bushman, R. L.: King and People in Provincial Massachusetts, Chapel Hill, NC, 1992.

Butel, Paul: The Atlantic, London and New York, Routledge, 1999.

Cahn, Mark D.: «Punishment, Discretion and the Codification of Prescribed Penalties in Colonial Massachusetts», American Journal of Legal History, XXXIII, 1989, 107-136.

Calloway, Colin G.: New Worlds for All: Indians, Europeans, and the Remaking of Early America, Baltimore and London, Johns Hopkins University Press, 1997.

Canny, Nicholas: «Writing Atlantic History; or, Reconfiguring the History of Colonial British America», Journal of American History, 86, 1999, 1093-1114.

Charlevoix, Pierre François Xavier de: Histoire et description général de la Nouvelle France avec le Journal Historique d'un voyage fait par l'ordre du Roi dans l'Amérique Septentrionnale, Paris, Rolin Fils Libraire, 1744, 3 vols.

Chauprade, Aymeric: Géopolitique. Constantes et changements dans l'histoire, Paris, Ellipses, 2007. 
Churchill, Winston S.: Marlborough: His Life and His Times. I: 1650-1688, New York, Charles Scribner's Sons, 1933.

Claydon, Tony: Europe and the Making of England, 1660-1760, Cambridge, Cambridge University Press, 2007.

Coclanis, Peter A.: «Drang Nach Osten: Bernard Bailyn, the World-Island, and the Idea of Atlantic History», Journal of World History, XIII, 1, 2002, 168-182.

Cohen, Daniel A.: Pillars of Salt, Monuments of Grace: New England Crime Literature and the Origins of American Popular Culture, 1674-1860, New York, Oxford University Press, 1993.

Colden, Cadwallader: The History of the Five Indian Nations of Canada, which are dependent on the Province of New York in America, and are the barrier between the English and French in that part of the world, London, Lockyer Davis, Wren and Ward, 1755, 2 vols.

Colebrook Harris, Richard: The seigneurial system in early Canada: a geographical study, Kingston (Ontario), McGill-Qeen's University Press, 1984.

Cook, E.: The Fathers of the Towns. Leadership and Community Structure in Eighteenth-Century New England, Baltimore, Johns Hopkins University Press, 1976.

Cordova-Bello, Eleazar: Compañías holandesas de navegación, agentes de la colonización neerlandesa, Sevilla, Escuela de Estudios HispanoAmericanos, CSIC, 1964.

Cressy, D.: Coming Over. Migration and Communication between England and New England in the Seventeenth Century, New York, Cambridge University Press, 1987.

Crouch, Nathaniel: The English Empire in America: Or a Prospect of His Majesties Dominions in the West-Indies, London, Nath. Crouch at the Bell in the Poultry near Cheapside, 1685.

Dechêne, Louise: Habitants et marchands de Montréal au XVIIe siècle, Montréal, Boréal, 1988.

Denis, Claude: We Are Not You: First Nations and Canadian Modernity, Peterborough (Ontario), Broadview Press, 1997.

Dickason, Olive Patricia: Canda's First Nations. A History of Founding Peoples from Earliest Times, Don Mills (Ontario), Oxford University Press, 1977.

Dickason, Olive Patricia: The myth of the savage and the beginnings of French colonialism in the Americas, Edmonton, University of Alberta Press, 1984.

Douville, Raymond y Casanova, Jacques-Donat: La vie quotidienne en NouvelleFrance. Le Canada, de Champlain a Montcalm, Paris, Hachette, 1964.

Dunn, Richard S.: «Seventeenth-Century English Historians of America», en Smith, James M. (ed.), Seventeenth-Century America: Essays in Colonial History, Chapel Hill, The University of North Carolina Press, 1959, 195-225.

Durand, George: Etats et Institutions, XVIe-XVIIIe siècles, Paris, Armand Colin, 1969. 
Duroselle, Jean-Baptiste: Tout Empire Périra. Théorie des relations internationales, Paris, Armand Colin, 1992.

Eccles, William John, Frontenac, the Courtier Governor, Toronto, McClelland and Stewart, 1959.

Eccles, William John: The Canadian Frontier, 1534-1760, Alburquerque, University of New Mexico Press, 1983.

Eccles, William John: Essays on New France, Toronto, Oxford University Press, 1987.

Eccles, William John: The French in North America, 1500-1783, Markham (Ontario), Fitzhenry and Whiteside, 1998.

Elliott, John H.: Britain and Spain in America: Colonist and Colonized, Reading, University of Reading, 1994.

Elliott, John H.: «Empire and State in British America», en Gruzinski, Serge y Wachtel, Nathan (eds.), Le Nouveau Monde-Mondes Nouveaux. L'expérience américaine, Paris, École des Hautes Études en Sciences Sociales, 1996.

Elliott, John H.: Do the Americas Have a Common History? An Address, Providence, RI, Associates of the John Carter Brown Library, 1998.

Faillon, Etienne Michel: Histoire de la colonie française en Canada, Villemarie, Bibliotheque Paroissiale, 1865.

Fischer, David Hackett: Albion' Seed: Four British Folkways in America, New York, Oxford University Press, 1989.

Force, Peter (coord.): Tracts and other papers, relating principally to the origin, settlement, and progress of the colonies in North America, from the discovery of the country to the year 1776, Whashington, Printed by WM. Q. Force, 1846, IV.

Foster, Stephen: The Long Argument: English Puritanism and the Shaping of New England Culture, 1570-1700, Chapel Hill, 1991.

Francis, A. D.: The Methuen and Portugal, Cambridge, Cambridge University Press, 1966.

Frostin, Charles: «Les Pontchartrain et la pénétration commerciale en Amérique espagnole (1690-1715)», Revue Historique, A-J, 1971, 307-336.

Gerard, James W.: The Peace of Utrecht. A historical review of the Great Treaty of 1713-14, and of the principal events of the War of the Spanish Succession, New York and London, Press of G. P. Putnam's Sons, 1885.

Gil Pujol, Javier: «Notas sobre el estudio del poder como nueva valoración de la historia política», Pedralbes, 3, 1983, 61-88.

Godbeer, Richard: The Devil's Dominion: Magic and Religion in Early New England, New York, Cambridge University Press, 1992.

Goddard, Peter A.: «The Devil in New France: Jesuit Demonology, 1611-50», The Canadian Historical Review, 1, 1997, 40-62.

González Seara, Luis: El poder y la palabra. Idea del Estado y vida política en la cultura europea, Madrid, Tecnos, 1995. 
JOSÉ MANUEL DE BERNARDO ARES

Gourmont, Remy de: Les Français au Canada et en Acadie, Paris, Firmin-Didot, 1888.

Gragg, Larry: The Salem Witch Crisis, Westport, Greenwood Publishing Group, 1992.

Graham, Geral S.: Canada. A short history, London, Hutchinson's University Library, 1950.

Granatstein, J. L.: Who Killed Canadian History, Toronto, Harper Colliins, 1998.

Graymont, Barbara (ed.): Early American Indian Documents: Treaties and Laws, 1607-1789. VII: New York and New Jersey Treaties, 1609-1682, New York, University Publications of America, 1985.

Greene, Jack P.: Peripheries and Center: Constitutional Development in the Extended Politics of the British Empire and the United Estates, 1607-1788, Athens, Norton, 1987.

Greene, Jack P.: The Intellectual Construction of America: Exceptionalism and Indentity from 1492 to 1800, Chapel Hill, The University of North Caroline Press, 1993.

Groulx, Patrice: Pièges de la mémoire.Dollard des Ormeaux, les Amerindiens et nous, Hull (Québec), Editions Vents de l'Ouest, 1998.

Hall, David D.: Worlds of Wonder, Days of Judgment, Popular Religious Belief in Early New England, New York, Alfred A. Knopf, 1989.

Hancock, David: "“A World of Business to Do": William Freeman and the Foundations of England's Commercial Empire, 1645-1707», William and Mary Quarterly. A Magazine of Early American History and Culture, LVII, 1, 2000, 3-34.

Hauptmann, L. M. y Wherry, J. D. (eds.): The Pequots in Southern New England. The Fall and Rise of an American Indian Nation, Norman, OK, 1990.

Henige, David P.: Colonial Governors from the Fifteenth Century to the Present. A Comprehensive List, Madison, University of Wisconsin Press, 1970.

Henneton, Lauric: Liberté, inégalité, autorité: Politique, société et construction identitaire du Massachusetts au XVIIe siècle, Paris, Honoré Champion, 2009.

Hernando Sánchez, Carlos José: «Repensar el poder. Estado, Corte y Monarquía Católica en la historiografía italiana», en Diez años de historiografía modernista, Bellaterra, Universitat Autònoma de Barcelona, 1997, 103-139.

Hinderaker, Eric: Elusive Empires. Constructing Colonialism in the Ohio Valley, 1673-1800, Cambridge, Cambridge University Press, 1999.

Howe, Daniel W., American History in an Atlantic context, Oxford, 1993.

Innis, Harold Adams, The Fur Trade in Canada. An introduction to Canadian Economic History, Toronto, University of Toronto Press, 1962.

Jetten, Marc: Enclaves amérindiennes: les «reductions» du Canada, 1637-1701, Sillery, Septentrion, 1994. 
Jones, Elisabeth: Gentlemen and Jesuits. Quest for glory and adventure in the early days of New France, Toronto, University of Toronto Press, 1986.

Jordan, David W.: Foundations of Representative Government in Maryland, 16321715, New York, Cambridge University Press, 1987.

Kennedy, Paul: The Rise and Fall of the Great Powers. Economic Change and Military Conflict from 1500 to 2000, London, Unwin Hyman Limited, 1990.

Lanctot, Gustave: A history of Canada. II: From the Royal Régime to the Treaty of Utrecht, 1663-1713, Toronto, Vancouver and London, Clarke, Irwin and Harrap Co., 1964.

Larose, François: Etude des séquences d'occupation iroquoienne et algonquienne avant 1700, Universidad de Québec à Montreal, Tesis doctoral, 1997.

Lenman, Bruce P.: Britain's Colonial Wars, 1688-1783, London, Longman, 2001.

Lenman, Bruce P.: England's Colonial Wars, 1550-1688. Conflicts, Empire and National Identity, London, Longman, 2001.

Lintvelt, Jaap; Ouellet, Réal y Hermans, Hub (dirs.): Culture et colonisation en Amérique du Nord: Canada, Etats-Unis, Mexique, Sillery (Québec), Septentrion, 1994.

Lorda i Alaiz, F.: «Del poder y sus fisonomías», Sistema. Revista de Ciencias Sociales, 84, 1988, 91-120.

Lorin, Henri: Le comte de Frontenac. Étude sur le Canada français à la fin du XVIIe siècle, Paris, Armand Colin, 1985.

Lounsbury, Ralph G.: The British Fishery at Newfoundland, 1634-1763, Yale, Archon Books, 1969.

Mann, B. H.: Neighbors and Strangers. Law and Community in Early Connecticut, Chapel Hill, The University of North Caroline Press, 1987.

Mann, Michael: Las fuentes del poder social. Una historia del poder desde los comienzos hasta 1760 d.C., Madrid, Alianza Ed., 1991.

Mardones, José María: «Teorías de la legitimación del poder hoy. J. Habermas y la teoría del discurso», Sistema. Revista de Ciencias sociales, 120, 1994, 39-58.

Martínez Shaw, Carlos y Oliva Melgar, José María (eds.): El sistema atlántico español (siglos XVII-XIX), Madrid, Marcial Pons Historia, 2005.

Massard, Fabienne: «Propriété seigneuriale et noblesse dans le gouvernement de Québec (1626-1759)», Etudes canadiennes/Canadian Studies, 38, 1995, 7-16.

Mather, Cotton: Magnalia Christi Americana: or, the Ecclesiastical History of New England from its planting in the year 1620 unto the year or our Lord 1698, London, Thomas Parkhurst, 1702.

Mathieu, Jacques: La Nouvelle-France. Les Français en Amerique du Nord, XVIeXVIIIe siècle, Québec, Belin et PUL, 1993.

McCusker, J. J. y Menard, R. R.: The Economy of British America, 1607-1789, Chapel Hill, The University of North Caroline Press, 1985. 
McMillan, Alan D.: Native Peoples and Cultures of Canada. An antrhopological Overview, Vancouver and Toronto, Douglas and McIntyre, 1995.

Meinig, D. W.: Atlantic America, 1492-1800, New Haven, Conn., 1986.

Merwick, Donna: Possessing Albany, 1630-1720. The Dutch and the English Experiences, Cambridge, Cambridge University Press, 2002.

Miller, Perry: The New England Mind: The Seventeenth Century, New York, 1939.

Miller, Perry: The New England Mind: From Colony to Province, Cambridge, Mass., The Belknap Press of Harvard University Press, 1998.

Morgan, E. S.: Inventing the People. The Rise of Popular Sovereignty in England and America, New York, Norton, 1988.

Morton, Desmond: A military history of Canada. For Champlain to the Gulf War, Toronto, McClelland and Stewart Inc., 1992.

Muldoon, James, Empire and Order. The Concept of Empire, 800-1800, London and New York, Macmillan Press and St. Martin's Press, 1999.

Muldoon, James: «Who Owns the Sea?», en Klein, Bernhard (ed.), Fictions of the Sea: Critical Perspectives on the Ocean in British Literature and Culture, Ashgate-Aldershot, Aldershot, 2002, 13-27.

Muldoon, James: Is the Sea Open or Closed? The Grotius-Selden Debate Renewed, en prensa a.

Muldoon, James: Christendom, The Americas, and World Order, en prensa b.

Nassiet, Michel: La France du second XVIIe siècle, 1661-1715, Paris, Belin, 1997.

Newell, Margaret Ellen: From dependency to Independence: Economic Revolution in Colonial New England, Ithaca and London, Cornell University Press, 1998.

Nobles, G. H.: Divisions throughout the Whole. Politics and Society in Hampshire County, Massachusetts, 1740-1760, New York, Cambridge University Press, 1983.

Oldmixon, John: The British Empire in America, containing the History of the Discovery, Settlement, Progress and Present State of all the British Colonies on the Continent and Islands of America, London, Printed for John Nicholson, Benjamin Tooke, Richard Parker and Ralph Smith, 1708, 2 vols.

Papers relating to an Act of the Assembly of the Province of New York, for encouragement of the Indian trade, etc., and for prohibiting the selling of Indian goods to the French, viz. of Canada, New York, William Bradford, 1724.

Pâquet, Martin; Sanfilippo, Matteo y Warren, Jean-Philippe (dirs.): Le Saint-Siège, le Québec et l'Amérique française. Les archives vaticanes, pistes et défis, Québec, Presses de l'Université Laval, 2013.

Parkman, Francis: Count Frontenac and New France under Louis XIV. France and England in North America, Little, Brown and Company, Boston, 1897, 2 vols.

Parkman, Francis: France and England in North America, New York, The Library of America, 1983. 
Pencak, W. y Wright, C. E. (eds.): Authority and Resistance in Early New York, New York, The President and Fellows of Harvard College, 1988.

Pisani, Edgar: «Commment conjuguer unité et diversité. Le Canada, laboratoire institutionnel à hauts risques», Le Monde Diplomatique, 526, 1998, 14-15.

Pocock, John Greville Agard: Politics, language and time: essays on political thought and history, London, Methuen, 1972.

Pritchard, James: In Search of Empire. The French in the Americas, 1670-1730, Cambridge, Cambridge University Press, 2004.

Pulsipher, Jenny H.: «"Our Sages are Sageles”: A Letter on Massachusetts Indian Policy after King Philip's War», William and Mary Quarterly. A Magazine of Early American History and Culture, LVIII, 2, 2001, 431-448.

Raimo, John W.: Biographical Directory of American Colonial and Revolutionary Governors, 1607-1789, Westport, Meckler Books, 1980.

Records of the Particulier Court of the colony of Connecticut. Administration of Sir Edmond Andros, Royal Governor, 1687-1688, Hartford, Connecticut, Lockwood and Brainard Company, 1935.

Rich, E. E.: The history of the Hudson's Bay Company, 1670-1870. I: 1670-1763, New York, The Macmillan Company, 1961.

Schultz, Eric B. y Tougias, Michael J.: King Philip's War. The History and Legacy of America's Forgotten Conflict, Woodstock, VT, The Countryman Press, 2000.

Several Treaties of Peace and Commerce concluded between the late King of blessed memory deceased, and other Princes and States, London, Printed by the Assigns of John Bill, and by Henry Hills, and Thomas Newcomb, 1685.

Shomette, Donald G. y Haslach, Robert D.: Raid on America. The Dutch Naval Campaign of 1672-1674, Columbia, SC, University of South Carolina Press, SC, 1988.

Stout, Harry S.: The New England Soul: Preaching and Religious Culture in Colonial New England, New York, Oxford University Press, 1986.

Traité de Neutralité conclu a Londres le seiziéme Novembre 1686 entre les Roys de France et d'Angleterre, touchant les pays des deux Roys en Amerique, Paris, Imprimerie de Frederic Leonard, 1686.

Turgeon, Laurier; Delage, Denys y Ouellet, Réal (eds.): Transfers culturels et métissages. Amérique/Europe. XVIe-XXe siécle, Québec et Paris, Presses de l'Université Laval et L'Harmattan, 1996.

Wallace, Anthony F. C.: «Origins of Iroquois Neutrality: The Settlement of 1701», Pennsylvania History, 24, 1957, 223-235.

Wallerstein, Inmanuel: Geopolítica y geocultura: ensayos sobre el moderno sistema mundial, Barcelona, Kairos, 2007.

Webb, Stephen Saunders: 1676. The End of American Independence, New York, Alfred A. Knopf, 1984. 
Webb, Stephen Saunders: The Governors-General. The English Army and the Definition of Empire, 1569-1681, Chapel Hill, NC, University of North Carolina Press, 1979.

Weisman, Richard: Witchcraft, Magic and Religion in Seventeenth-Century Massachusetts, Amherst, 1984.

Whitmore, W. H. (ed.): The Andros tracts, being a collection of pamphlets and official papers issued during the period between the overthrow of the Andros government and the establishment of the second charter of Massachusetts, New York, Burt Franklin, 1968.

Wilbur, C. Keith: The New England Indians. An illustrated source book of authentic details about everyday Indian life, Chester, CT, The Globe Pequot Press, 1978.

Zahedieh, Nuala: The Capital and the Colonies. London and the Atlantic Economie, 1660-1700, Cambridge, Cambridge University Press, 2010. 